\title{
Tax planning as an effective method to reduce the tax burden of organizations in the Russian Federation.
}

\author{
Elena Sivolapenko ${ }^{1, *}$ and Ekaterina Sapozhnikova ${ }^{1}$ \\ ${ }^{1}$ Don State Technical University, 344003, Gagarin sq., 1, Rostov-on-Don, Russia
}

\begin{abstract}
Taxes are an integral part of the economic system, not only of any state, but also of each individual organization. The influence of the tax system on the state and development of the economy is an indisputable fact. Tax planning is an effective tool to reduce the tax burden of organizations in the Russian Federation. However, today it is not a recognized method of reducing the costs of an organization, despite its cost-effectiveness, legality and stability. The purpose of this article is to study the tax planning method as an effective tool to reduce the tax burden used by organizations in the Russian Federation. The result of the study is the analysis of the calculations of the tax burden of the organization when applying various tax regimes provided for by the current legislation for individual entrepreneurs.
\end{abstract}

\section{Introduction}

The main goal of any commercial organization is not only to make a profit, but also to systematically increase it. Each business entity achieves this goal in different ways, some reduce the cost of production by purchasing cheaper raw materials, or make changes in the production cycle of the enterprise, the latter expand the range of goods and services produced by occupying new market niches, and others rely on investing in others activities that generate additional income. One thing remains unchanged - the interdependence of two parallel processes - increasing profits and reducing costs.

The search for the optimal, and most importantly, effective and long-term method of reducing enterprise costs is, on the one hand, the main task of any enterprise, on the other hand, its main problem, which explains the relevance of the study. For example, Abey Francis in his article "Cost Reduction - Meaning and Techniques" identifies 5 main traditional methods of cost reduction: Target Costing, Activity-based Costing, Just in Time, Enterprise Resource Planning, Value Engineering (VE) [1]. Kevin Coyne, Shawn T. Coyne and Edward J. Coyne, Sr. in their publication When You've Got to Cut Costs - Now, the most effective method of reducing administrative costs is a combination of several methods, accompanied by a constant search for new ideas [2].

\footnotetext{
*Corresponding author : vladimirovnale95@mail.ru
} 
Despite the fact that the materials of the scientific literature today highlight dozens of effective methods of reducing costs, taking into account the specific features of organizations in various fields of activity, none of the researchers singles out tax planning as an independent method of reducing enterprise costs, which this article is devoted to in detail..

\section{Materials and methods}

It is undeniable that taxes are an integral part of the economic system not only of any country, but also of each individual organization [3]. And, despite the traditionally inherent imperativeness of tax payments, modern tax systems are characterized by a certain kind of discretion, which manifests itself in the ability of a taxpayer to plan his tax payments and choose tax regimes [4]. The purpose of this article is to study the tax planning method as an effective tool to reduce the tax burden used by organizations in the Russian Federation.

The current norms of the legislation of the Russian Federation directly provide for the right of the taxpayer to tax planning, which is confirmed by the decision of the Constitutional Court of the Russian Federation of May 27, 2003. No. 9-p, according to which "it is unacceptable to establish responsibility for such actions of a taxpayer, which, although they result in non-payment of tax or a decrease in its amount, but consist in the use of the rights granted to the taxpayer by law, related to exemption on a legal basis from tax or with the choice of the most profitable forms of entrepreneurial activity for him and, accordingly, the optimal type of payment ". This resolution is a kind of tax planning manifesto, in which, for the first time in Russian legislation, the taxpayer's right to legally reduce the amount of tax liabilities was officially enshrined.

Article 21 of the Tax Code of the Russian Federation also enshrines the taxpayer's rights to tax planning, providing for the right to use tax incentives if there are legal grounds for this [5].

Another normative legal act confirming the legal right of a taxpayer to tax planning is the resolution of the Plenum of the Supreme Arbitration Court of the Russian Federation dated October 12, 2006. No. 53 "On the assessment by arbitration courts of the validity of the taxpayer's receipt of tax benefits." This resolution for the first time fixed the concept of "tax benefit", which means a decrease in the amount of tax liability due, in particular, to a decrease in the tax base, obtaining a tax deduction, tax incentives a lower tax rate, as well as obtaining the right to a refund (offset) or tax refund from the budget.

Thus, all of the above regulatory legal acts confirm the right of the taxpayer to reduce the tax burden of Russian enterprises by implementing an efficiently constructed tax planning model. However, it is important to understand that this right of taxpayers in the Russian Federation is not unlimited. The norms of tax, administrative and criminal law of the Russian Federation provide for liability for tax planning implemented by a taxpayer using techniques that violate the norms of Russian legislation, which results in deliberate tax evasion by the taxpayer.

The study of the Russian judicial practice on tax crimes related to the use by taxpayers of methods to reduce the amount of tax liabilities gives us a rather contradictory picture of the implementation of the taxpayer's right to tax planning. Thus, the result of the system analysis carried out was the identification of three independent types of tax planning:

1. Legal tax planning;

2. Tax planning based on abuse of law;

3. Illegal tax planning.

This classification is based on the criterion of legality, as one of the basic principles of the rule of law. In the first case, it means tax planning, which involves the use of legal means of optimizing taxation, enshrined in the legislation of the Russian Federation. 
Illegal tax planning implies that the taxpayer commits actions (inaction) aimed at reducing the tax burden, contrary to the requirements of the legislation based on the use of illegal tax schemes.

Tax planning based on abuse of law is an intermediate link between the two considered types and is rightfully recognized as one of the most difficult from the point of view of legal classification. The fact is that a taxpayer, applying one or another scheme for optimizing tax payments, when using tax planning based on abuse of law, from a formal point of view, does not violate the requirements of the law, however, on the issue of the validity of obtaining a specific tax benefit from judicial and tax authorities doubts arise. In most cases recorded in Russian judicial practice, doubts are related to the transparency and legality of the reasons and conditions for the application of tax benefits (benefits). As an example, we can cite cases widespread in Russian judicial practice when taxpayers abuse the right to freedom of contract, provided for in Article 421 of the Civil Code of the Russian Federation. Using this right in practice, taxpayers often deliberately conclude those types of contracts for which less taxes are charged, despite the fact that the nature of the transaction suits a completely different type [6].

Having considered these types of tax planning from the point of view of the following factors: 1. Time period, 2. Economic efficiency, 3. Legality and 4. Stability, we see that the most long-term, stable and legal method of tax planning is recognized (Figure 1). The longterm and stability of this method is due to the fact that the tax legislation of the Russian Federation, despite its dynamic development, develops every year not only in terms of tightening legal norms, but also in the direction of expanding the provision of tax benefits to certain categories of taxpayers, which explains the long-term prospect of applying this type of tax planning.

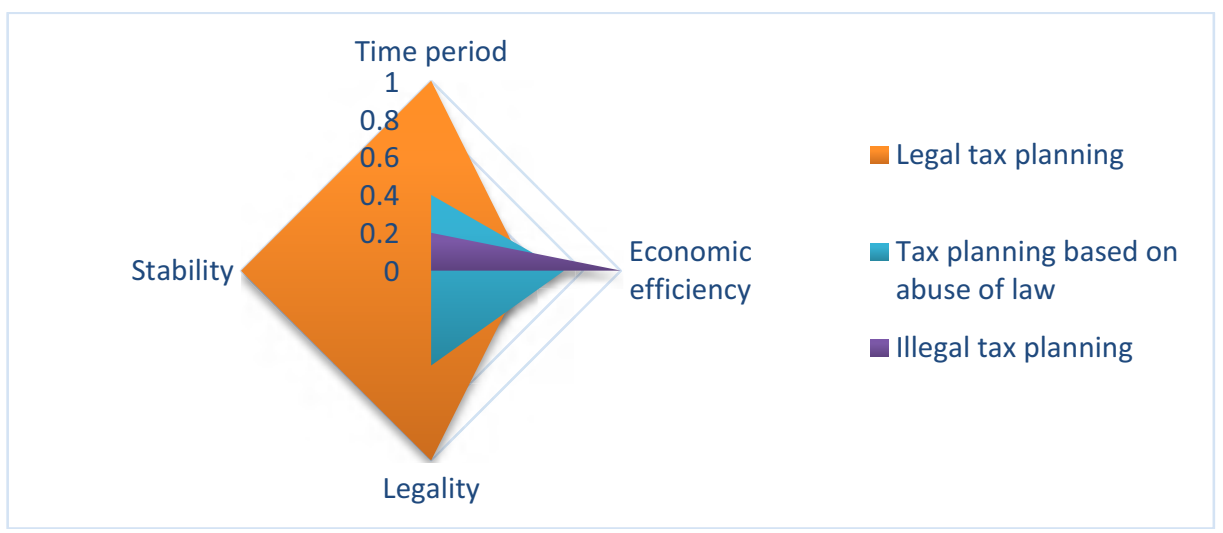

Fig. 1. Analysis of types of tax planning according to the main criteria of efficiency

Separately, it is worth noting the fact that the system of tax benefits in the Russian Federation is developed not only at the federal level, but also at the level of the subjects of the Federation and municipalities. According to article 56 of the Tax Code of the Russian Federation, the constituent entities of the federation are entitled to establish and cancel tax incentives for regional taxes (with the exception of the tax on gambling business), municipalities for local taxes.

Speaking about the economic efficiency of this type of tax planning, it is important to note that despite the fact that the level of economic effect is much lower than that of other types, the overall set of economic results is characterized by a high level of stability. This is due not only to long-term programs for the provision of tax benefits and the application of special tax regimes, but also by the fact that in the event of the cancellation of a specific tax 
benefit, no additional tax amounts will be charged, since legislative acts of the Russian Federation on taxes and fees that worsen the situation of taxpayers, reverse have no force (Article 5 of the Tax Code of the Russian Federation) [5].

Tax planning based on abuse of law, although it can be quite effective from an economic point of view, has high risks and is usually short-term and unstable. As for illegal tax planning, the only advantage of this type is only economic benefit. The use of such a scheme is a large and unjustified risk for any enterprise, the result of which may be not only penalties provided for by the Tax Code of the Russian Federation, the Code of Administrative Offenses of the Russian Federation, but also punishments in the types of imprisonment provided for by the Criminal Code of the Russian Federation [5- 8].

Speaking about the effectiveness of tax planning as a method of reducing the tax burden of organizations in the Russian Federation, it is worth noting that this definition rightfully includes not only the economic, but also the legal component, therefore, in more detail, this article will consider the first one, and in our opinion the only admissible type of tax planning is legal tax planning [9-10].

The main tool for the implementation of legal tax planning in an organization is the correct application and use of preferential taxation regimes provided for by current legislation. The preferential taxation system in the Russian Federation is represented not only by the ability to reduce certain types of tax payments (tax deduction, tax exemptions), but also by a wide range of special tax regimes.

Today special tax regimes include 6 independent regimes:

1) taxation system for agricultural producers (unified agricultural tax);

2) a simplified taxation system;

3) a taxation system in the form of a single tax on imputed income for certain types of activities;

4) the taxation system in the implementation of production sharing agreements;

5) patent taxation system;

6) tax on professional income (as an experiment) (Article 18 of the Tax Code of the Russian Federation) [5].

Each of the presented modes has its own key features and limitations, enshrined in current legislation. The main task of tax planning of any organization is to use the most effective tool to reduce the tax burden, which allows to achieve the maximum reduction in the company's expenses in the long term.

The main difficulty of the effective application of tax planning lies in a well-built system of analysis of the specific features of a particular organization and a detailed calculation of all possible options and schemes for reducing the size of tax payments. Using the example of a specific organization, we will show how the total volume of the tax burden of an enterprise differs depending on the selected tax regime [11-12].

As an example, let us take an individual entrepreneur IP Ivanov I.I., whose main activity is sewing clothes according to the individual order of the population (OKVED code 13.99.9). The staff of the organization in question consists of 3 people directly involved in sewing clothes, including the individual entrepreneur himself. Suppose that the average income of the studied organization is 400 thousand rubles per month, current expenses are 150 thousand rubles, 70 thousand of which is the salary of employees (30 thousand are the salary of an individual entrepreneur, 20 thousand are each of the employees).

We will calculate the total amount of the tax payment of a given organization, provided that the organization applies tax regimes suitable for it, namely the general taxation regime, a simplified system or a taxation system in the form of a single tax on imputed income. The result of these calculations will be a comparison of the size of the tax payment when using different tax regimes of the studied organization. 
When using the simplified taxation system, namely the tax base in the form of income, the organization must pay tax in the following amount: 400,000 rubles $* 6 \% * 12$ months $=$ 288,000 rubles per year. It should also be noted that the current legislation provides for an additional benefit for individual entrepreneurs who have hired employees, which means that the taxpayer can reduce the amount of tax by the amount of paid insurance premiums, but not more than $50 \%$. The amount of insurance premiums paid by the organization per year will be: 70,000 rubles $* 30 \% * 12$ months $=252,000$ rubles. Thus, the total amount of tax payable under the simplified taxation system (tax base - income), minus the amount of insurance premiums, will be 288,000 rubles / $2=144,000$ rubles per year.

When using the same taxation system, but taking into account the tax base in the form of income minus expenses, an individual entrepreneur must pay tax in the amount of: $(400,000$ rubles $-150,000$ rubles $) * 15 \% * 12$ months $=450,000$ rubles per year. The amount of the calculated tax cannot be reduced by the paid contributions, since they have already been taken into account in the total amount of the organization's expenses.

Let's calculate the size of the tax payment under the special tax regime - a single tax on imputed income. The tax amount in this case is calculated as the product of the basic profitability for a certain type of entrepreneurial activity, calculated for the tax period, the value of the physical indicator characterizing this type of activity and the tax rate $(15 \%)$, while the data of the deflator coefficient (K1) and the correcting coefficient K2 were taken as of 2020 . Thus, the size of the tax payment under this system will be $3 * 7500$ rubles * $2.009 * 0.4 * 15 \% * 12$ months $=32,545.8$ rubles. Also, individual entrepreneurs who switched to UTII and make payments to employees are entitled to reduce (but not more than $50 \%$ ) the amount of the calculated UTII by the amount of contributions and benefits paid in this tax period only for employees. Thus, the amount of insurance payments to employees will be 40,000 rubles $* 30 \% * 12$ months $=144,000$ rubles. The amount of tax payable under the special tax regime, the single tax on imputed income is 16,272.9 rubles per year.

It remains to calculate the size of the tax payment under the general taxation regime, in which the organization remains automatically, if it does not independently switch to any of the available special tax regimes. According to the current legislation, the organization must pay value added tax (VAT) and income tax. The amount of value added tax will be 400,000 rubles $* 12$ months $* 20 \%=960,000$ rubles. Income tax $-((4,800,000$ rubles $960,000$ rubles) $-150,000$ rubles $* 12$ months $) * 20 \%=408,000$ rubles. Thus, the aggregate amount of tax payment for the organization under the general taxation regime will amount to $1,368,000$ rubles per year.

\section{Results}

Based on the presented calculations, we see that in this case for an individual entrepreneur the most favorable taxation regime is a single tax on imputed income, and the most ineffective will be the application of the general taxation regime.

It is important to note that the size of the tax payment when using the general taxation regime is 84 times greater than when using the single tax on imputed income regime, which once again proves to us the efficiency and importance of tax planning in the organization. As we can see, even choosing the wrong tax base can entail large overpayments. So, for example, when using a simplified taxation system (tax base - income), the total amount of tax payment is more than 3 times less than when applying the same tax regime, but when choosing a tax base, income minus expenses [13].

\section{Conclusions}


The presented calculations clearly demonstrate not only the importance, but also the need to apply tax planning in the activities of any organization, regardless of the number of employees and the volume of annual income. The size of the tax benefit presented also shows us the significance and economic efficiency of the method under consideration and proves to us the need to bring this method into an independent method of reducing the costs of the enterprise [14-15].

It is important to note that many modern organizations in the context of the economic crisis prefer to use methods aimed at reducing labor costs and purchasing cheaper raw materials that reduce the cost of production. The consequence of the application of these methods is not only economic benefits, which have a beneficial effect on the enterprise, but also an increase in unemployment and often a decrease in the quality of products. At the same time, we see that legislatively enshrined methods, a striking example of which is tax planning, if used correctly and competently, can provide a much more obvious economic effect, and allow achieving the desired results without any negative consequences.

\section{References}

1. A. Francis, Cost Reduction - Meaning and Techniques, MBA Knowledge Base, 2018, Available at: https://www.mbaknol.com/operations-management/cost-reductionprogram/ (Last accessed 05 September 2020)

2. K. Coyne , S. T. Coyne, E. J. Coyne, Sr. , Harvard Business Review, 2010 , Available at: https://hbr.org/2010/05/when-youve-got-to-cut-costs-now (Last accessed 05 September 2020)

3. Q. Hong, M. Smart, European Economic Review, 54, 82-95 (2010) doi: 10.1016/j.euroecorev.2009.06.006

4. M. Coopera, T. K. Quyen, Nguyen, International Business Review, 29 (2020) doi: 10.1016/j.ibusrev.2020.101692

5. "Tax Code of the Russian Federation (Part One)" dated July 31, 1998 N 146-FZ (as amended on April 1, 2020).

6. "Civil Code of the Russian Federation (part one)" dated 30.11.1994 N 51-FZ (as amended on 31.07.2020)

7. "Code of the Russian Federation on Administrative Offenses" dated 30.12.2001 N 195FZ (as amended on 31.07.2020) (as amended and supplemented, entered into force on 11.08.2020)

8. "The Criminal Code of the Russian Federation" dated 13.06.1996 N 63-FZ (as amended on 31.07.2020)

9. L. S. Kirina, N. A. Nazarova, Advances in intelligent systems and computing, 622, 476-484 (2018) doi : 10.1007/978-3-319-75383-6_61.

10. N.V. Serdyukova, K. L. Potapov, Smart innovation, systems and technologies, 99, 94103 (2019), doi : 10.1007/978-3-319-92363-5_9.

11. A. V. Grishin, Studies in computational intelligence, 826, 707-713 (2019), doi: 10.1007/978-3-030-13397-9_75.

12. M. Serikova, L. Sembiyeva, A. Shakharova, K. Balginova, G. Alina, A. Kurmanalina, 7, 2419-2435 (2020) doi : 10.9770/jesi.2020.7.3(64).

13. N. V. Serdyukova, I. M. Kolpashnikov, Smart innovation, systems and technologies, 188, 503-512 (2020) doi : 10.1007/978-981-15-5584-8_42. 
14. G. V. Fedotova, A. A. Gontar, R. H. Ilyasov, V. M. Ksenda, Studies in systems, decision and control, 182, 217-228 (2019) doi : 10.1007/978-3-030-01514-5_25.

15. G. Dubauskas, Journal of security and sustainability issues, 8, 775-784 (2019), doi: 10.9770/jssi.2019.8.4(19). 